\title{
Bacterial pneumonia in HIV-infected patients: a prospective study of 68 episodes
}

\author{
V. Falcó*, T. Fernández de Sevilla*, J. Alegre*, J. Barbé*, A. Ferrer**, \\ I. Ocaña*, E. Ribera*, J.M. Martínez-Vázquez*
}

Bacterial pneumonia in HIV-infected patients: a prospective study of 68 episodes. $V$. Falcó, T. Fernández de Sevilla, J. Alegre, J. Barbé, A. Ferrer, I. Ocaña, E. Ribera, J.M. Martínez-Vázquez. CERS Journals Ltd 1994.

ABSTRACT: We collected clinical and microbiological observations, as well as follow-up on human immunodeficiency virus (HIV)-infected patients with bacterial pneumonia, and compared pneumococcal pneumonia in patients with and without HIV infection.

Fifty five HIV-infected patients, who had had 68 episodes of bacterial pneumonia, were studied prospectively. Twenty one HIV-infected patients with pneumococcal pneumonia were compared to 69 non-HIV-infected patients with pneumococcal pneumonia.

Aetiological diagnosis was established in 48 cases $(71 \%)$. The most common causative agents were $S$. pneumoniae and $H$. influenzae. Sixty percent of episodes took place in asymptomatic carriers of HIV infection and $37 \%$ in acquired immune deficiency syndrome (AIDS) patients. Overall mortality was $10 \%$. Fifty five percent of patients with follow-up had recurrent episodes. Bacteraemic pneumococcal pneumonia was more frequent in HIV- than in non-HIV-infected patients, and the mortality of pneumococcal pneumonia was also higher in HIV- $(19 \%)$ than in nonHIV-infected $(4.3 \%)$ patients.

We conclude that bacterial pneumonia is a frequent problem in HIV-infected patients and that recurrent episodes are common. The clinical presentation of pneumococcal pneumonia is generally indistinguishable from that occurring in normal hosts, but bacteraemia is more common and the mortality is higher in HIVinfected patients.

Eur Respir J., 1994, 7, 235-239.
Depts of *Internal Medicine and **Microbiology, Hospital General Vall d'Hebrón, Universidad Autónoma, Barcelona, Spain.

Correspondence: V. Falcó Ferrer

c/ Sant Genís, 54

08340 Vilassar de Mar

Barcelona

Spain

Keywords: Acquired immune deficiency syndrome

bacterial pneumonia

human immunodeficiency virus

Received: March 161993

Accepted for publication October 31993
In the early years of the acquired immune deficiency syndrome (AIDS) epidemic, it was thought that opportunistic infections and neoplasms related to AIDS were directly caused by a progressive alteration of cellmediated immunity, and that humoral immunity was not only intact but also overreactive, based on findings of elevated immunoglobulin levels, elevated levels of antibody to specific viral agents and normal to elevated numbers of B-cells $[1,2]$. However, increased rates of bacterial pneumonias in human immunodeficiency virus (HIV)infected patients were reported in the following years [3-6]. The attack rate for pneumococcal pneumonia in HIV-infected patients is $18-45$ per 1,000 , which is significantly higher than the yearly estimated incidence rate for pneumococcal pneumonia in the general population, which is 3 per $1,000[4,7]$. Selwyn et al. [8], in a prospective study of 159 intravenous drug users, found that $9 \%$ of seropositive patients had a bacterial pneumonia, while the incidence was only $2 \%$ in seronegative patients. YAMAGUCHI et al. [9] observed that the incidence of pneumococcal pneumonia in patients with HIV infection increased from $2 \%$ in 1985 to $9 \%$ in 1989.
Because bacterial pneumonia is the most prominent complication associated to B-cell dysfunction, it was thought that HIV-infected patients had B-cell abnormalities associated with the profound T-cell deficiency caused by HIV. Different authors have demonstrated marked abnormalities of B-cell activation and immunoregulation, directly at the level of the B-cell, as well as at the level of T-cell control of B-cell function [10-12].

In our hospital, we have also noticed an increasing incidence of bacterial pneumonia in HIV-infected patient; this led us to conduct a prospective study of all patients with HIV infection and community-acquired bacterial pneumonia, in order to record clinical and microbiological observations as well as follow-up data in these patients, and also to compare the clinical features of pneumococcal pneumonia in patients with and without HIV infection.

\section{Material and methods}

From February 1988 to October 1990, all patients with HIV infection who had a community-acquired bacterial 
pneumonia were prospectively studied. Bacterial pneumonia was defined as an acute lower respiratory tract disease with fever $\left(>38^{\circ} \mathrm{C}\right)$, and pulmonary infiltrates in $\mathrm{X}$-ray chest film not seen on prior radiographs and/or resolving after antibiotic therapy. Patients in whom chest roentgenogram abnormalities were attributed to congestive heart failure, pulmonary embolus or chronic underlying lung disease were excluded. Patients with right-sided endocarditis, metastatic pulmonary infection, pulmonary tuberculosis, Pneumocystis carinii pneumonia and obstructive pneumonitis due to lung cancer were also excluded.

For each patient, we recorded clinical and routine laboratory data and chest roentgenogram observations. On admission, all patients were instructed to deliver a sputum sample as soon as possible. Blood cultures were carried out in each patient before therapy was started. All sputum samples were cultured for Legionella sp. Sputum specimens were cultured for bacteria only if $>25$ polymorphonuclear leucocytes and $<10$ squamous epithelial cells were present per low-power field on Gram-stain [13]. After homogenization, quantitative sputum culture with a gauged handle was performed in all cases. All patients were treated with a third generation cephalosporin.

A micro-organism was considered to be the causative agent of pneumonia when at least one of the following criteria was present: 1) visualization of the microorganism by Gram-stain of sputum and isolation of more than $5 \times 10^{6}$ (colony forming unit) $\mathrm{cfu} \cdot \mathrm{ml}^{-1}$ in quantitative sputum culture; 2) isolation of the micro-organism in blood cultures and/or pleural fluid.

Respiratory failure was considered when blood gas level showed severe hypoxaemia (arterial oxygen tension $\left.\left(\mathrm{PaO}_{2}\right)<60 \mathrm{mmHg}(8 \mathrm{kPa})\right)$ without oxygen administration. Shock was defined by clinical signs (systolic arterial pressure $<80 \mathrm{mmHg}$, tachycardia, urine output $<20 \mathrm{ml} \cdot \mathrm{h}^{-1}$, and clinical signs of reduction of tissue perfusion).

HIV antibodies were determined by enzyme immunoassay and confirmed by western-blot. Patients with HIV infection were classified according to Center of Disease Control (CDC) criteria (1987): Group I (primary infection); Group II (asymptomatic carrier); Group III (persistent generalized lymphadenopathy); and Group IV (AIDS).

Clinical and evolutive data of patients with HIV infection and pneumococcal pneumonia were compared to those of 69 non-HIV-infected patients with pneumococcal pneumonia. This control group of HIV negative patients was obtained from a prospective study of all community-acquired pneumonias carried out in our hospital at the same time. There were 51 males and 18 women, with a mean age of 58 yrs.

A statistical analysis was performed using the Chisquared test, or Fisher's exact test when expected values were $<5$, to compare categorical variables. A multivariate analysis was performed using a regression model to compare pneumococcal pneumonias in patients with and without HIV infection and to obtain independent variables to predict mortality.

\section{Results}

During the period of the study, 68 episodes of community-acquired pneumonia were diagnosed in 55 patients with HIV infection. There were 39 males and 16 females, with a mean age of 31 yrs (range 20-61 yrs). Forty six patients were intravenous drug users, four had haemophilia, three were heterosexual partners of HIV-infected patients, one was homosexual, and the remaining acquired the infection after blood transfusion.

Forty one episodes $(60 \%)$ took place in asymptomatic carriers of HIV (Group II), two in patients with persistent generalized lymphadenopathy (Group III) and 25 patients already had an AIDS diagnosis (Group IV). The opportunistic diseases in patients with an AIDS diagnosis before the bacterial pneumonia are listed in table 1. Thirty seven patients were under oral zidovudine therapy and 32 were receiving prophylaxis for Pneumocystis carinii pneumonia (27 with sulphamethoxazoletrimethoprim and 5 with inhaled pentamidine). The length of time from the diagnosis of HIV infection to the development of bacterial pneumonia varied from 1-60 months (mean 18 months). Fifteen of the 55 patients had no previous diagnosis of HIV infection when they had the bacterial pneumonia.

In table 2 clinical, laboratory and radiological findings in HIV-infected patients with bacterial pneumonia are summarized. Nearly all patients presented with fever

Table 1. - Opportunistic diseases in 25 AIDS patients with bacterial pneumonia

$\begin{array}{lr}\text { Pneumocystis carinii pneumonia } & 12 \\ \text { Extrapulmonary tuberculosis } & 8 \\ \text { Recurrent Salmonella enteritidis bacteraemia } & 5 \\ \text { Brain toxoplasmosis } & 3 \\ \text { Disseminated cryptococcosis } & 3 \\ \text { Oesophageal candidiasis } & 1 \\ \text { Progressive multifocal leucoencephalopathy } & 1 \\ \text { Disseminated cytomegalovirus disease } & 1 \\ \text { Cryptosporidiosis } & 1\end{array}$

AIDS: acquired immune deficiency syndrome.

Table 2. - Clinical presentation, laboratory and radiological findings in 68 episodes of 55 HIV-infected patients with bacterial pneumonia

\begin{tabular}{lrr}
\hline & \multicolumn{2}{c}{ Episodes } \\
& $\mathrm{n}$ & $\%$ \\
\hline Fever & 68 & 100 \\
Productive cough & 59 & 87 \\
Chest pain & 50 & 74 \\
Respiratory failure & 15 & 22 \\
Shock & 4 & 6 \\
White cell count $<4 \times 10^{9} \cdot l^{-1}$ & 21 & 31 \\
White cell count $>10 \times 10^{9} \cdot l^{-1}$ & 23 & 34 \\
Unilateral infiltrate & 60 & 88 \\
Bilateral infiltrates & 8 & 12 \\
Pleural effusion & 8 & 12 \\
Cavitation & 4 & 6 \\
\hline
\end{tabular}

HIV: human immunodeficiency virus. 
(100\%), productive cough (87\%) and chest pain (74\%). Severe complications, such as respiratory failure, were present in 15 patients $(22 \%)$. Intubation and mechanical ventilation were necessary in two cases. The initial white blood cell count was elevated in only one third of cases, and was below $4 \times 10^{9} \cdot l^{-1}$ in another third. Although all patients had radiological signs of consolidation, only $62 \%$ had physical signs of pneumonia, eight patients had bilateral infiltrates, and eight had pleural effusion. When cavitation was present on the X-ray film (table 2) the aetiological agents were Streptococcus pneumoniae, Bacillus sphericus, Acinetobacter calcoaceticus and Streptococcus sp.

An aetiological diagnosis of bacterial pneumonia was established in 48 cases. The most common causative agents were $S$. pneumoniae, which caused 23 episodes (34\%), and $H$. influenzae, which was responsible for 12 cases $(18 \%)$. Other organisms isolated were P. aeruginosa in four patients, and other Gram-negative bacilli in four cases. The remaining microorganisms were responsible for only one case each (table 3 ). Bacteraemia was detected in 19 cases.

We have compared 21 pneumococcal pneumonias in HIV-infected patients with 69 pneumococcal pneumo-

Table 3. - Aetiology of community-acquired bacterial pneumonia (68 episodes) in 55 HIV-infected patients

\begin{tabular}{lrl}
\hline Streptococcus pneumoniae & 22 & $(34 \%)$ \\
Haemophilus influenzae & 12 & $(18 \%)$ \\
Pseudomonas aeruginosa & 4 & \\
Other Gram-negative bacilli & 4 & \\
Staphylococcus aureus & 1 & \\
Bacillus sphericus & 1 & \\
Mycoplasma pneumoniae & 1 & \\
Moraxella catarrhalis & 1 & \\
Streptococcus spp. & 1 & \\
Total & 48 & $(71 \%)$ \\
& & \\
Unknown & 20 & $(29 \%)$ \\
\end{tabular}

HIV: human immunodeficiency virus. nias in non-HIV infected patients (table 4). In the univariate analysis, non-HIV-infected patients were more likely to have chronic obstructive lung disease as underlying condition $(\mathrm{p}<0.01)$, purulent sputum $(\mathrm{p}<0.01)$ and signs of chest consolidation $(\mathrm{p}<0.01)$. Patients with HIV infection and pneumococcal pneumonia more frequently had chronic liver disease $(\mathrm{p}<0.05)$, bacteraemia $(\mathrm{p}<0.05)$ and a higher mortality $(\mathrm{p}<0.05)$.

In the multivariate analysis, only physical signs of chest consolidation were more frequent in non-HIV-infected patients $(\mathrm{p}<0.01$; odds ratio $=12)$, and bacteraemia was more frequently detected in $\mathrm{HIV}$-infected patients $(\mathrm{p}<0.01$; odds ratio $=4$ ).

Thirteen patients (19\%) had a total lymphocyte count below $0.5 \times 10^{9} \cdot l^{-1}, 28(41 \%)$ between 0.5 and $1 \times 10^{9} \cdot l^{-1}$, and $27(40 \%)$ more than $1 \times 10^{9} \cdot l^{-1}$. Twenty four out of 31 patients $(77 \%)$ had a total CD4 count below $0.2 \times 10^{9} \cdot l^{-1}$.

Seven patients died, giving an overall mortality of $10 \%$. When we compared patients who died with those who survived, we found the following factors to be associated with a higher mortality: development of respiratory failure $(\mathrm{p}<0.05)$, shock $(\mathrm{p}<0.05)$, more than one lobe involved in $\mathrm{X}$-ray chest film $(\mathrm{p}<0.05)$, presence of pleural effusion $(\mathrm{p}<0.05)$ and an absolute lymphocyte count below $1 \times 10^{9} \cdot l^{-1}$. However, the multivariate analysis showed that the only independent variables to predict mortality were pleural effusion $(\mathrm{p}<0.01$; odds ratio $=46)$ and an absolute lymphocyte count below $1 \times 10^{9} \cdot l^{-1}(\mathrm{p}<0.01$; odds ratio 4 ).

Thirty one patients were followed up for 1-31 months after they had recovered from pneumonia. Seventeen of them had another bacterial pneumonia after recovering from the previous episode. Twelve of these patients were receiving co-trimoxazole for primary or secondary prevention of $P$. carinii pneumonia. The recurrent episodes developed in the first 2 months in 10 patients. Seven out of 16 patients that were asymptomatic carriers of HIV developed an AIDS defining condition in a mean time of 10 months.

Table 4. - Comparison between HIV-infected patients with pneumococcal pneumonia (Group 1) and non-HIVinfected patients with pneumococcal pneumonia (Group 2)

\begin{tabular}{|c|c|c|c|c|c|c|}
\hline & \multicolumn{2}{|c|}{$\begin{array}{c}\text { Group } 1 \\
\text { HIV-infected }\end{array}$} & \multicolumn{2}{|c|}{$\begin{array}{c}\text { Group } 2 \\
\text { non-HIV-infected }\end{array}$} & \multirow[t]{2}{*}{$\begin{array}{c}\text { Univariate } \\
\text { analysis }\end{array}$} & \multirow[t]{2}{*}{$\begin{array}{l}\text { Multivariate } \\
\text { analysis }\end{array}$} \\
\hline & $\mathrm{n}$ & $\%$ & $\mathrm{n}$ & $\%$ & & \\
\hline Number of patients & 21 & & 69 & & & \\
\hline Smokers & 18 & 86 & 36 & 52 & $\mathrm{p}<0.01$ & \\
\hline Chronic obstructive lung disease & 0 & & 26 & 38 & $\mathrm{p}<0.01$ & \\
\hline Chronic liver disease & 6 & 29 & 5 & 7 & $\mathrm{p}<0.05$ & \\
\hline Productive cough & 20 & 95 & 64 & 93 & & \\
\hline Purulent sputum & 8 & 38 & 52 & 75 & $\mathrm{p}<0.01$ & \\
\hline Chest pain & 13 & 62 & 40 & 58 & & \\
\hline Chest consolidation & 14 & 67 & 66 & 96 & $\mathrm{p}<0.01$ & $\mathrm{p}<0.01(\mathrm{OR}=12)$ \\
\hline Respiratory failure & 6 & 29 & 17 & 25 & & \\
\hline Shock & 3 & 14 & 8 & 12 & & \\
\hline Bacteraemia & 15 & 71 & 28 & 41 & $\mathrm{p}<0.05$ & $\mathrm{p}<0.01(\mathrm{OR}=4)$ \\
\hline Mortality & 4 & 19 & 3 & 4 & $\mathrm{p}<0.05$ & \\
\hline
\end{tabular}

OR: odds ratio; HIV: human immunodeficiency virus. 


\section{Discussion}

The incidence of bacterial pneumonia is increased in HIV-infected patients $[4,7,8,14-16]$. In our study we describe 68 episodes of bacterial pneumonia, which actually constitutes one of the largest series.

An aetiological diagnosis was obtained in nearly $71 \%$ of cases. A majority of community-acquired bacterial pneumonias seen in AIDS patients are caused by Streptococcus pneumoniae and Haemophilus influenzae [4, 7, $8,17]$. Both micro-organisms were the causative agents in more than $50 \%$ of our patients. Other organisms such as Legionella pneumophila, which is the second agent of community-acquired pneumonia in our hospital [18], is very unusual [19]. Although Staphylococcus aureus was responsible for $6 \%$ of respiratory complications in HIV-infected patients in one study [20], it has been the cause of only one case in our series.

Four patients had a pneumonia caused by Pseudomonas aeruginosa. All of these patients had an advanced stage of HIV infection with a very low lymphocyte count, although they also had granulocytopenia as a predisposing factor to $P$. aeruginosa infection. However, of nine AIDS patients with community-acquired pneumonia caused by $P$. aeruginos $a$ in the study reported by FRANZETTI $e t$ al. [21], none had granulocytopenia, suggesting that the occurrence of Pseudomonas aeruginosa pneumonia should certainly be regarded as an indicator of progression of immunodeficiency. Recently, FrIED and ROMANO [22] have also reported four cases of pneumonia caused by $P$. aeruginosa in AIDS patients; therefore, it should be considered that $P$. aeruginosa is not a rare cause of pneumonia in HIV-infected patients, especially in those with an advanced stage of immunosuppression. Mycoplasma pneumoniae is unusual in these patients [23].

An important point to consider is that 15 of the 55 patients $(27 \%)$ had no diagnosis of HIV infection, so that bacterial pneumonia was the first manifestation of HIV infection. Some authors, therefore, stress the need to investigate the possibility of HIV infection in any young adult without an underlying disease and presenting with $S$. pneumoniae or $H$. influenzae pneumonia [24-27].

In general, the clinical presentation of bacterial pneumonia in HIV-infected patients is similar to that occurring in non-HIV-infected patients. Most patients have an acute onset of symptoms, and signs of fever, productive cough and chest pain are present in nearly all cases [28]. Although we found some differences in the clinical presentation of pneumococcal pneumonia between HIV-infected and non-infected patients, we think that, in general, they are not relevant. Atypical presentations or manifestations of pneumococcal disease are not frequent in HIV-infected patients, and the serotypes causing pneumococcal infection are the same in HIV- and non-HIV-infected patients [29]. It is important to note that bacteraemia is significantly more frequent in HIVinfected patients with pneumococcal pneumonia and the mortality is also higher. The higher rate of bacteraemia, which has been documented in other studies [30-33], is probably related to impairment of humoral immunity.
Forty three $(63 \%)$ episodes of bacterial pneumonia took place in patients who had no previous opportunistic disease. SELwyn et al. [8] also reported that about $66 \%$ of their HIV-infected patients with bacterial pneumonia had no signs of an advanced stage of HIV infection. Bacterial pneumonia seems to be an early manifestation in the natural history of HIV infection, but we have to consider that $77 \%$ of patients had a total CD4 lymphocyte count below 200 cells $\cdot \mathrm{mm}^{3}$. In nearly half of the patients ( 7 of 16) who were asymptomatic carriers of HIV (Group II), an AIDS defining disease developed within a mean period of 10 months. HIV-infected patients with bacterial pneumonia may thus already have an important impairment of their immunological mechanisms, hence bacterial pneumonia could be a marker of progression to AIDS. PARKIN et al. [34] similarly observed that patients with bacterial infections, especially pneumonias, had a higher incidence of cytomegalovirus disease and Pneumocystis carinii pneumonia.

Despite the high incidence of bacteraemia and the impairment of their immunological system, the majority of patients responded to antimicrobial therapy; the mortality rate was $10 \%$. Although mortality for pneumococcal pneumonia seemed higher in HIV-infected patients than in non-HIV-infected patients, multivariate analysis did not confirm this observation. In a recent study, AIDS patients with bacteraemic pneumococcal pneumonia had a mortality of $57 \%$, which was significantly higher than the $25 \%$ seen in patients without HIV infection. However, HIV-infected patients without AIDS had a $100 \%$ survival rate [35]. In other studies, the mortality rate for bacteraemic pneumococcal pneumonia in patients with HIV infection has been relatively low, ranging from $5-11 \%$ [36, 37]; thus, it seems that the prognosis of bacteraemic pneumococcal pneumonia depends on the stage of HIV infection.

Despite the good response to treatment, recurrent episodes of bacterial pneumonia are common in these patients. In one study, 10 out of 17 patients with bacterial pneumonia had a recurrent episode [38]. Seventeen of 31 of our patients had another bacterial pneumonia within a mean of 5 months after recovery. It has also been noted that recurrent bacterial pneumonias may be associated with advanced HIV disease, suggesting a worse prognosis [36]. Undoubtedly, studies on preventive strategies should be performed in order to reduce this high rate of recurrence.

\section{References}

1. Masur H, Michelis MA, Green JB, et al. An outbreak of community-acquired Pneumocystis carinii pneumonia. N Engl J Med 1981; 305: 1431-1438.

2. Stahl RS, Friedman-Kien A, Dubin R, Marmor R, Zolla-Pazner S. Immunologic abnormalities in homosexual men. Relationship to Kaposi's sarcoma. Am J Med 1982; 73: 171-178.

3. Krumholz HM, Sande MA, Lo B. Community-acquired bacteremia in patients with acquired immunodeficiency syndrome: clinical presentation, bacteriology, and outcome. Am J Med 1989; 86: 776-779. 
4. Polsky B, Gold JWM, Whimbey E, et al. Bacterial pneumonia in patients with acquired immunodeficiency syndrome. Ann Intern Med 1986; 104: 38-41.

5. Simberkoff MS, Sadr WE, Schiffman G, Rahal Jr JJ. Streptococcus pneumoniae infection and bacteremia in patients with acquired immunodeficiency syndrome, with report of a pneumococcal vaccine failure. Am Rev Respir Dis 1984; 130: 1174-1176.

6. White S, Tsou E, Walhorn RE, Katz P. Life-threatening bacterial pneumonia in male homosexuals with laboratory features of the acquired immunodeficiency syndrome. Chest 1985; 87: 486-488.

7. Witt DW, Craven DE, McCabe WR. Bacterial infections in adult patients with the acquired immunodeficiency syndrome (AIDS) and AIDS-related complex. Am J Med 1987; 82: 900-906.

8. Selwyn PA, Feingold AR, Hartel D, et al. Increased risk of bacterial pneumonia in HIV-infected intravenous drug users without AIDS. AIDS 1988; 2: 267-272.

9. Yamaguchi E, Charache $\mathrm{P}$, Chaisson RE. Increasing incidence of pneumococcal infection associated with HIV infection in an inner city hospital, 1985-1989. 1990 World Conference on Lung Health. Am Rev Respir Dis 1990; 141 (Suppl.): A619.

10. Lane HC, Masur H, Edgar LC, Whalen G, Rook AH, Fauci AS. Abnormalities of B-cell activation and immunoregulation in patients with the acquired immunodeficiency syndrome. N Engl J Med 1983; 309: 453458.

11. Amman AJ, Schiffman G, Abrams D, Volberding P, Ziegler J, Conant M. B-cell immunodeficiency in acquired immunodeficiency syndrome. J Am Med Assoc 1984; 251: 1447-1449.

12. Pahwa SG, Quilop MTJ, Lange M, Pahwa RN, Grieco MH. Defective B-Lymphocyte function in homosexual men in relation to the acquired immunodeficiency syndrome. Ann Intern Med 1984; 101: 757-763.

13. Murray PR, Washington JA. Microscopic and bacteriologic analysis of expectorated sputum. Mayo Clin Proc 1975; 50: 339-344.

14. Repáraz J. Infecciones bacterianas en pacientes con síndrome de inmunodeficiencia adquirida. Enf Infec Microbiol Clin 1991; 9: 297-307.

15. Magnenat JL, Nicod LP, Auckenthaler R, Junod AF. Mode of presentation and diagnosis of bacterial pneumonia in human immunodeficiency virus-infected patients. Am Rev Respir Dis 1991; 144: 917-922.

16. Teira R, Zubero Z, Muñoz J, Alvarez M, Cisterna R, Santamaría JM. Neumonía por bacterias no oportunistas en pacientes infectados por VIH. Incidencia y valoración de una aproximación no invasiva. Enf Infec Microbiol Clin 1992; 10: 11-16.

17. Whimbey E, Gold JWM, Polsky B, et al. Bacteremia and fungemia in patients with the acquired immunodeficiency syndrome. Ann Intern Med 1986; 104: 511514.

18. Falcó V, Fernández de Sevilla T, Alegre J, Ferrer A, Martínez-Vázquez JM. Legionella pneumophila: a cause of severe acquired pneumonia. Chest 1991; 100: 1007-1011.

19. Allan AA, Kamholz SL. Legionella pneumonia and AIDS. Chest 1989; 95: 707-708.

20. Levine SJ, White DA, Fellos AOS. The incidence and significance of Staphylococcus aureus in respiratory cultures from patients infected with human immunodeficiency virus. Am Rev Respir Dis 1990; 141: 89-93.
21. Franzetti F, Cernuschi M, Esposito R, Moroni M. Pseudomonas infection in patients with AIDS and AIDSrelated complex. J Intern Med 1992; 231: 437-443.

22. Fried ED, Romano PM. Pseudomonas pneumonia in AIDS patients. 1990 World Conference on Lung Health. Am Rev Respir Dis 1990; 141 (Suppl.): A605.

23. Petitjean J, Quibriac M, Lechevalier B, Brouard J, Freymuth F. Infections respiratoires à Mycoplasma pneumoniae au cours du syndrome d'immunodéficience acquise. Presse Méd 1988; 17: 1762.

24. Schlamm HT, Yancovitz SR. Haemophilus influenzae pneumonia in young adults with AIDS, ARC, or risk of AIDS. Am J Med 1989; 86: 11-14.

25. Chirurgi VA, Edelstein H, McCabe R. Pneumococcal bacteremia as a marker for HIV infection without AIDS. Sixth International Conference on AIDS. San Francisco 1990; 2: 386.

26. Pesanti EL, Lyons RW, Verilli M, Levitz R, Brettman L. Infection with the human immunodeficiency virus (HIV) as a risk factor for bacteremic illness due to Streptococcus pneumoniae. Conn Med 1988; 52: 703-704.

27. Johnson DP. Community-acquired pneumonia in AIDS. Conn Med 1988; 52: 735-736.

28. Cohn DL. Bacterial pneumonia in the HIV-infected patient. Infect Dis Clin North Am 1991; 5: 485-507.

29. Redd SC, Rutherford GW, Sande MA, et al. The role of human immunodeficiency virus infection in pneumococcal bacteremia in San Francisco residents. J Infect Dis 1990; 162: 1012-1017.

30. Pesanti EL, Lyons RW, Verrill M, Levitz R, Brettman L. Pneumococcal bacteremia in young adults. An association with seropositivity to human immunodeficiency virus (HIV) infection. Am Rev Respir Dis 1987; 135 (Suppl.): A168.

31. Moreno S, García-Leoni ME. Neumonía neumocócica y VIH. Enf Infec Microbiol Clin 1991; 9: 263-264.

32. Roca V, Pérez-Cecilia E, Viñuelas J, Ferreiros J, Coello R, Picazo JJ. Bacteriemia por Streptococcus pneumoniae e infección por VIH. Enf Infec Microbiol Clin 1991; 9: 268-271.

33. García-Leoni ME, Moreno S, Rodeño P, Cercenado E, Vicente T, Bouza E. Pneumococcal pneumonia in adult hospitalized patients infected with the human immunodeficiency virus. Arch Intern Med 1992; 152: 1808-1812.

34. Parkin JM, Rowland-Hill CA, Shaw RJ, Scott KE, Pinching AJ. Pyogenic infections in patients with AIDS and a possible role of IVIG in the treatment of functional hypogammaglobulinemia. Vox Sang 1987; 52: 173.

35. Pesola GR, Charles A. Pneumococcal bacteremia with pneumonia. Mortality in acquired immunodeficiency syndrome. Chest 1992; 101: 150-155.

36. Janoff EN, Breiman RF, Doley CL, Hopewell PC. Pneumococcal disease during HIV infection. Epidemiologic, clinical and immunologic perspectives. Ann Intern Med 1992; 117: 314-324.

37. Teira R, Muñoz J, Zubero Z, Rojo P, Cisterna R, Santamaría JM. Características epidemiológicas de la bacteriemia neumocócica en la era del SIDA. Enf Infec Microbiol Clin 1992; 10: 138-142.

38. Gerberding JL, Krieger J, Sande MA. Recurrent bacteremic infection with $S$. pneumoniae in patients with AIDS virus infection (Abstract 443). Program and abstracts of the 26th Interscience Conference on Antimicrobial Agents and Chemotherapy. American Society for Microbiology 1986; 177. 